\title{
Viewpoints
}

\section{Regulation of Synaptic Transmission and Plasticity by Protein Phosphatase 1}

\author{
(Darl Foley, ${ }^{1}$ Cody McKee, ${ }^{1}{ }^{-1}$ Angus C. Nairn, ${ }^{2}$ and Houhui $\mathrm{Xia}^{3}$ \\ ${ }^{1}$ Neuroscience Graduate Program, Department of Neuroscience, University of Rochester Medical Center, Rochester, New York 14642, ${ }^{2}$ Department \\ of Psychiatry, Yale University School of Medicine, New Haven, Connecticut 06511, and ${ }^{3}$ Department of Pharmacology and Physiology, University of \\ Rochester Medical Center, Rochester, New York 14642
}

Protein phosphatases, by counteracting protein kinases, regulate the reversible phosphorylation of many substrates involved in synaptic plasticity, a cellular model for learning and memory. A prominent phosphatase regulating synaptic plasticity and neurologic disorders is the serine/threonine protein phosphatase 1 (PP1). PP1 has three isoforms $(\alpha, \beta$, and $\gamma$, encoded by three different genes), which are regulated by a vast number of interacting subunits that define their enzymatic substrate specificity. In this review, we discuss evidence showing that PP1 regulates synaptic transmission and plasticity, as well as presenting novel models of PP1 regulation suggested by recent experimental evidence. We also outline the required targeting of PP1 by neurabin and spinophilin to achieve substrate specificity at the synapse to regulate AMPAR and NMDAR function. We then highlight the role of inhibitor-2 in regulating PP1 function in plasticity, including its positive regulation of PP1 function in vivo in memory formation. We also discuss the distinct function of the three PP1 isoforms in synaptic plasticity and brain function, as well as briefly discuss the role of inhibitory phosphorylation of PP1, which has received recent emphasis in the regulation of PP1 activity in neurons.

Key words: protein phosphatase 1; inhibitor-2; synaptic transmission; neurabin; LTP; LTD

\section{Introduction}

Protein phosphorylation on serine (Ser) or threonine (Thr) residues is a ubiquitous and powerful cellular regulatory mechanism that allows rapid and reversible modulation of receptors and signaling pathways. In humans, the number of Ser/Thr kinases exceeds Ser/Thr-phosphatases $\sim 10$-fold (Hendrickx et al., 2009), making these phosphatases major nodes in intersecting signaling networks. Protein phosphatase 1 (PP1) is one of the major Ser/ Thr protein phosphatases in all tissues and cell types, and is particularly abundant in brain (da Cruz e Silva et al., 1995; Ouimet et al., 1995; Sharma et al., 2015; Uhlen et al., 2015), which is the focus of this review article. The three genes encoding PP1 give rise to three isoforms ( $\mathrm{PP} 1 \alpha, \mathrm{PP} 1 \beta, \mathrm{PP} 1 \gamma)$ with a highly conserved catalytic core. The PP1 catalytic subunit, $\sim 330$ amino acids long, is a globular enzyme with three putative substrate binding surface grooves emanating from the active site: the Cterminal, acidic, and hydrophobic grooves (Fig. 1A). Each of the three surface grooves on PP1 may bind amino acids close to the target Ser or Thr residue with different physiochemical

Received Sep. 11, 2020; revised Feb. 8, 2021; accepted Feb. 9, 2021.

This work was supported by National Institutes of Health R01 MH109719 and National Science Foundation IOS-1457336 to H.X.; and National Institutes of Health F30 MH122046 to K.F. Research in the laboratory of A.C.N. was supported by National Institutes of Health AG047270, AG062306, AG066508, and DA018343 and the State of Connecticut Department of Mental Health and Addiction Services. Figures were created in part using Servier Medical Art images (https://smart.servier.com), licensed under a Creative Commons Attribution 3.0 Unported License.

The authors declare no competing financial interests.

Correspondence should be addressed to Houhui Xia at houhui_xia@urmc.rochester.edu.

https://doi.org/10.1523/JNEUROSCI.2026-20.2021

Copyright $(2021$ the authors properties (ionic, hydrophobic, etc). They collectively accommodate binding to a diverse array of substrates, estimated to be in the thousands (Heroes et al., 2013). This is in contrast to protein kinases, which typically recognize only one so-called local "consensus" amino acid sequence close to the target Ser or Thr. The PP1 catalytic subunit in isolation thus does not have much substrate specificity beyond Ser and Thr residues and is sometimes referred to as a "promiscuous" enzyme (Heroes et al., 2013; but see studies on bacteria-expressed recombinant PP1, e.g., Hoermann et al., 2020).

\section{PP1 holoenzymes confer substrate specificity}

PP1 dephosphorylates a wide variety of proteins, yet does so in a highly regulated manner. PP1's substrate specificity comes from binding of the catalytic subunit to a large family of targeting proteins (Bollen et al., 2010) (Fig. 1B). These targeting proteins function not only to bring PP1 into physical proximity with its substrates, but also to restrict binding to other proteins (Ragusa et al., 2010) and/or create a new composite surface for substrate binding (Fedoryshchak et al., 2020) (Fig. 1C). The PP1 catalytic subunit typically forms a dimer by interacting in a mutually exclusive manner with a single targeting subunit, but higherorder PP1 holoenzymes have been identified.

With respect to binding of the PP1 catalytic subunit to its targeting proteins, there are several protein-docking sites on PP1 that accommodate short, linear motifs (SLiMs). The first identified and most common SLiM that mediates PP1 binding is the RVxF motif (Egloff et al., 1997; Kwon et al., 1997; Wakula et al., 2003; Heroes et al., 2013), which binds to a docking site on PP1 opposite to its catalytic active site (Fig. 1A). Additional SLiMs 

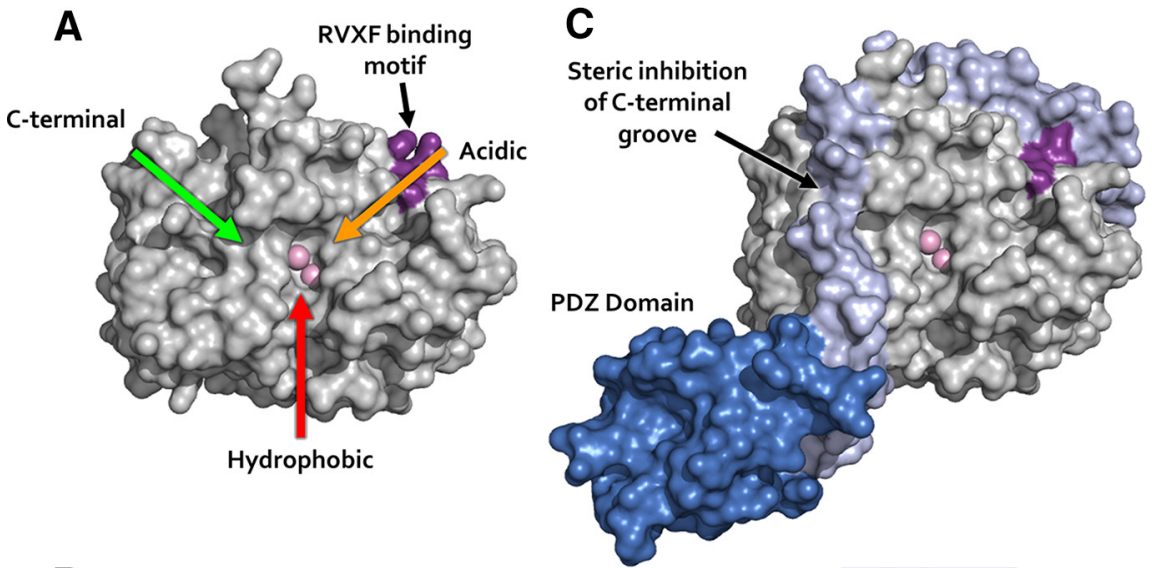

B

Mitochondria
LMTK1
Bad
BCL-x
Casp9
TEFM
CHCHD3/6
Nucleus
NIPP1
PNUTS
ERBIN
BCL2
NEK2a
PTEN
ATM
ELFN2
PPP1R3F
NOM1

Figure 1. PP1 active site and PP1 targeting. $\boldsymbol{A}, \mathrm{PP} 1 \alpha$ structure showing the active site (with two metal ions in light pink color) and the three grooves (colored arrows) radiating from the active site. $\boldsymbol{B}$, Schematic showing examples of PP1 interacting proteins in various subcellular compartments in neurons. Localization data are based on the Human Protein Atlas (Uhlen et al., 2015; Thul et al., 2017) and postsynaptic density proteomics (Bayes et al., 2011). C, Example of PP1 targeting protein neurabin fragment binding to PP1 $\alpha$ : in addition to using the RVxF binding mode (dark pink), neurabin (light purple) binds to the C-terminal groove of PP1, excluding a subset of PP1 substrates, such as phosphorylase $\alpha$ from the neurabin/PP1 holoenzyme (Ragusa et al., 2010). A, C, Structures were generated using PDB file 3hvq published by Ragusa et al. (2010).

have since been identified, such as the SILK, inhibitor-2 (I-2) docking site for the hydrophobic and acidic grooves and myosin phosphatase N-terminal element motifs that further promote binding to PP1. A notable example is the $\phi-\phi-\mathrm{R}-\mathrm{W}$ motif, located immediately after the RVxF motif on neurabin, growth arrest and DNA damage-inducible 34 (GADD34), PP1 nuclear targeting subunit, and phosphatase and actin regulator, that binds to and occludes the C-terminal groove on PP1, restricting binding of other proteins (Figurov et al., 1993; Ragusa et al., 2010; Choy et al., 2014, 2015; R. Chen et al., 2015). Some of the SLiMs may also compete for binding to PP1 in higher-order PP1 complexes. For example, in the I-2-PP1 dimer, I-2 makes contacts with PP1 with all three of its motifs: RVxF, SILK, and I-2 docking site for the hydrophobic and acidic grooves (Hurley et al., 2007). However, in the neurabin-PP1-I-2 trimeric complex, neurabin's RVxF motif wins out while I-2 interacts with PP1 only via the SILK and I-2 docking site for the hydrophobic and acidic groove motifs (Dancheck et al., 2011).

Through the identification and mutagenesis of these SLiMs, specific PP1 holoenzymes may be disrupted, and the functional consequences can be studied. This level of understanding will pave the way for targeted, rather than nonselective, pharmacological regulation of PP1 activity, of relevance to numerous disorders. Of note, the first selective PP1 holoenzyme drug, which targets the GADD34-PP1 complex, was recently identified and has shown promising therapeutic potential for a variety of conditions, including in models of neurodegeneration (Tsaytler et al., 2011; Das et al., 2015; Carrara et al., 2017).

Although the SLiMs are crucial for PP1 binding, there are additional residues on targeting proteins involved in PP1 binding. This is highlighted by preferential binding of certain targeting proteins to specific PP1 isoforms (TerryLorenzo et al., 2002b; Terrak et al., 2004; Trinkle-Mulcahy et al., 2006; Carmody et al., 2008; Booth et al., 2014; Kumar et al., 2016; Bertran et al., 2019). The three PP1 isoform sequences are highly conserved, including the major SLiM docking motifs, but there is variation in their $\mathrm{N}$ - and C-termini that likely accounts for their different binding affinities. The different binding affinities to targeting proteins lead to differences in localization and substrate specificity between the PP1 isoforms. In this way, PP1 isoforms may represent distinct pools of PP1 holoenzymes in different subcellular compartments. Indeed, our knowledge of the function of different PP1 isoforms is mainly deduced from immunolocalization studies. Specifically, the concentrated synaptic spine localization of PP1 $\alpha$ and PP1 $\gamma$ (Ouimet et al., 1995) suggests their importance in synaptic plasticity. Consistent with this view, neurabin, which plays a critical role in LTD and LTP induction as a PP1 targeting protein ( $\mathrm{Hu}$ et al., 2006), binds preferentially to PP1 $\gamma$ in the brain (via neurabin immunoprecipitation studies). In vitro neurabin also binds with highest affinity to $\operatorname{PP} 1 \gamma$, to a lesser degree with $\operatorname{PP} 1 \alpha$, and with minimal binding to PP1 $\beta$ (Terry-Lorenzo et al., 2002b; Carmody et al., 2004). Despite these differences in binding affinities, a compensatory increase in binding can occur when the dominant PP1 isoform is not present. For example, in brain extracts from PP1 $\gamma$ KO mice, neurabin immunoprecipitation pulls down PP1 $\alpha$ as well as small amounts of PP1 $\beta$ (Shirish Shenolikar, personal communication). These compensatory effects make it difficult to delineate the full range of in vivo functions of individual PP1 isoforms. Nevertheless, in the striatum, it has been found that $\mathrm{PP} 1 \alpha$ and PP1 $\gamma$ play opposite roles in reward learning and motivation (Andrade and Nairn, 2009), suggesting that the function of PP1 $\alpha$ and PP1 $\gamma$ depends on brain region as well as their interactions with targeting proteins.

PP1 $\beta$ localization in DIV7 primary hippocampal neurons is mainly limited to soma (Strack et al., 1999), but the major targeting protein(s) mediating this localization is unclear. Similarly, 
$\operatorname{PP} 1 \beta$ localization in the PFC of adult monkeys is 4 times more enriched in dendrites than in spines, whereas the reverse is true for PP1 $\alpha$ and PP1 $\gamma$ (Bordelon et al., 2005). PP1 $\beta$ is thus traditionally ignored in synaptic plasticity research. However, studies suggest that myosin phosphatase targeting subunit 1 , a PP1 $\beta$ specific binding protein, is localized in both presynaptic termini and postsynaptic spines in cortical synaptosomes (Lontay et al., 2004, 2012) (Fig. 1B) and auditory synapses (Lontay et al., 2012). Pharmacological studies suggest that PP1 $\beta$ could play a critical role in these synapses via the regulation of the phosphorylation status of presynaptic proteins, such as SNAP25 (Horváth et al., 2017). Moreover, whole exome sequencing studies have identified $>17$ patients with de novo $\mathrm{PP} 1 \beta$ mutations (P49R, A56P, E183A/V, D252Y, D274K, and Y304Ifs) who suffer from developmental delay, intellectual disability, deficits in social interactions, and in some cases anxiety and/or epilepsy (Hamdan et al., 2014; Gripp et al., 2016; Ma et al., 2016; Bertola et al., 2017; Zambrano et al., 2017; Lin et al., 2018), suggesting that PP1 $\beta$ could play a critical role in synaptic plasticity as well as neurodevelopment.

Consistent with the large number of PP1 holoenzymes, PP1 is involved in diverse physiological processes, including general phenomena, such as cell mitosis, as well as specific physiological processes, such as synaptic plasticity in neurons. PP1 generally is thought to inhibit learning and memory and has been dubbed a "molecule of forgetfulness" (Genoux et al., 2002). Although PP1 is known to play critical roles in synaptic plasticity (Mulkey et al., 1993, 1994; Jouvenceau et al., 2006) and memory (Genoux et al., 2002; Koshibu et al., 2009), how its activity and targeting are regulated in hippocampal and cortical neurons has only recently begun to be elucidated. In this review, we assess existing literature suggesting a role for brain PP1 in synaptic transmission and plasticity, and then discuss recent research that elaborates the underlying PP1 regulatory proteins and mechanisms. Specifically, we highlight the role of I-2 in regulating PP1 function in plasticity and memory formation, and the required targeting of PP1 by neurabin and spinophilin to achieve substrate specificity at the synapse. We also discuss the role of inhibitory phosphorylation of PP1, which has received recent emphasis in the regulation of PP1 enzymatic activity in neurons.

\section{PP1 regulates hippocampal synaptic plasticity}

The strength of synaptic transmission is defined by the magnitude of the postsynaptic response to presynaptic neurotransmitter release. Synaptic plasticity is the activity-dependent modulation of this postsynaptic response that, at glutamatergic synapses, is characterized by a change in the postsynaptic AMPAR response to glutamate. Many studies of PP1 have focused on its role in CA1 pyramidal neurons in the hippocampus, a brain region critical for multiple forms of learning and memory. Plasticity at synapses between Schaffer collateral (Sch) and hippocampal CA1 pyramidal cells is mediated by changes in postsynaptic AMPAR number and conductance in dendritic spines induced by AMPAR trafficking and phosphorylation (Malinow and Malenka, 2002). Sustained potentiation of synaptic transmission lasting more than $1 \mathrm{~h}$ also requires changes in the nucleus, including activation of transcription factors, such as $\mathrm{cAMP} /$ calcium responsive element binding protein (Barco et al., 2002; Deisseroth et al., 2003) whose target genes are important for long-term memory.

PP1 is a major Ser/Thr phosphatase enriched in dendritic spines (Ouimet et al., 1995; Strack et al., 1999; Terry-Lorenzo et al., 2000) as well as in the nucleus (Trinkle-Mulcahy et al., 1999), where it dephosphorylates diverse, important substrates that control various aspects of synaptic plasticity and memory. These substrates include Ser831 and Ser845 of the AMPAR subunit GluA1 (Lee et al., 2000; Hu et al., 2007), Ser1303 and Ser1480 on NR2B (Raveendran et al., 2009; Chiu et al., 2019), Thr286 of CaMKII (Strack et al., 1997), Ser133 of cAMP/calcium responsive element binding protein (Bito et al., 1996; Gao et al., 2009), Ser9 of GIRK2 (Chung et al., 2009), multiple phosphorylation sites on stargazin (Tomita et al., 2005) and the Kv2.1 potassium channel (Siddoway et al., 2013a), Ser10 of Histone H3 (Koshibu et al., 2011), and potentially many other proteins whose phosphorylation is regulated by, and also could regulate, synaptic activity (Siddoway et al., 2014). Additionally, epigenetic modifications, such as histone acetylation and methylation, which can influence learning and memory, are regulated by PP1 indirectly (Koshibu et al., 2009, 2011; Graff et al., 2010).

Early electrophysiological studies showed that PP1 is activated by (Thiels et al., 1998) and required for (Mulkey et al., 1993) LTD, whereas PP1 is inhibited during LTP (Blitzer et al., 1998). The inhibition of PP1 enzymatic activity, either through incubation with pharmacological reagents or direct injection of small protein inhibitors into neurons, blocked LTD induction in hippocampal CA1 neurons (Morishita et al., 2001). The same effect was seen with direct injection of short peptides containing the $\mathrm{RVxF}$ motif, which are known to block the interaction between PP1 and its targeting proteins. This indicates that PP1 targeting, in addition to its activity, likely plays a critical role in LTD induction. Additionally, there is evidence for a doseresponse relationship between PP1 inhibition and the induction of synaptic plasticity (Jouvenceau et al., 2006). Partial inhibition of PP1 activity ( $\sim 68 \%)$ in a transgenic mouse expressing a constitutively active PP1 protein inhibitor led to a shift toward potentiation in the frequency-dependent induction of synaptic potentiation versus depression, such that synaptic depression was reduced following low-frequency stimulation and synaptic potentiation was increased following high-frequency stimulation (Jouvenceau et al., 2006). Regulation of PP1 activity is not only important during the induction of synaptic plasticity, but also in the events following induction. Both PP1 activity and targeting are necessary for the maintenance of LTD expression (Mulkey et al., 1993; Morishita et al., 2001); and, consistent with this, suppression of PP1 activity is critical for the expression of late-phase LTP and long-term memory (Blitzer et al., 1998; Woo et al., 2002; Brush et al., 2004; Vecsey et al., 2007).

Although many studies have focused on PP1's role in Hebbian synaptic plasticity as a molecular constraint on learning and memory, PP1 also plays a role in homeostatic synaptic plasticity, which refers to the negative feedback response to a chronic neuronal hyperactivity or inactivity (Turrigiano et al., 1998). For example, in primary cortical neurons treated with bicuculline, a $\mathrm{GABA}_{\mathrm{A}}$ receptor antagonist that blocks inhibitory neuron activity, the initial increase in neuronal activity was reduced over time (many hours to days). We have shown that PP1 is involved in this negative feedback (Siddoway et al., 2013b). During this process of synaptic downscaling, PP1 activity toward AMPARs increases, resulting in GluA2 Ser880 dephosphorylation; blocking this dephosphorylation attenuates synaptic downscaling (Siddoway et al., 2013b). On the other hand, during TNF $\alpha$ induced synaptic upscaling, PP1 decreases inhibitory synapse transmission via regulating $\beta 3$ subunit of $\mathrm{GABA}_{\mathrm{A}}$ receptors (Pribiag and Stellwagen, 2013). 
A

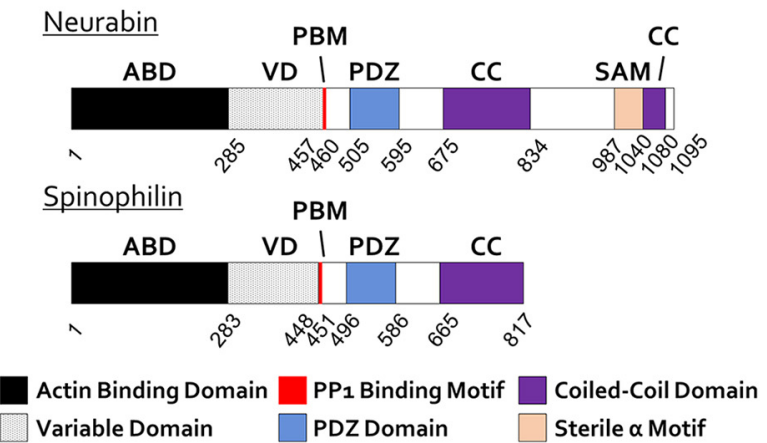

B

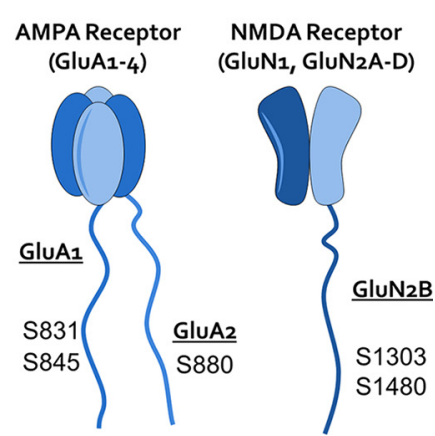

Figure 2. Structure of synaptic PP1 scaffolding proteins neurabin and spinophilin, and their potential dephosphorylation sites on AMPAR and NMDAR. $A$, Domain structures of neurabin and spinophilin. $\boldsymbol{B}$, Topology as well as potential dephosphorylation sites of neurabin/PP1 holoenzymes on AMPAR and NMDAR.

PP1 has many other functions beyond synaptic plasticity in the CNS. For example, PP1 appears to be important for stabilizing synaptic transmission ( $\mathrm{Hu}$ et al., 2007), as will be described later, and its activity can reduce inflammatory pain signaling in the spinal cord (Hu et al., 2015). Additionally, PP1 activity can confer neuroprotective properties: Consistent with LTD being a physiological, instead of pathologic, phenomenon, activation of PP1 during LTD promotes recovery from oxygen-glucose deprivation (OGD) in vitro and from ischemia in vivo (Hedou et al., 2008). The nuanced and varied roles of PP1 in the nervous system highlight the importance of elucidating the functions of specific PP1 holoenzymes and their regulation.

\section{PP1 targeting proteins in synaptic plasticity}

There is strong evidence that PP1 regulates synaptic plasticity, but it is also involved in a wide variety of physiological processes. Each function of PP1 in vivo is mediated by a specific holoenzyme comprising a PP1 catalytic subunit in association with one or more regulatory subunits. Therefore, connecting each individual PP1 holoenzyme with specific physiological processes is a prerequisite for rational drug design and modification of PP1 activity. What then is the identity of the associated PP1 scaffolding protein required for LTD induction? Among the hundreds of PP1 scaffolding proteins, two have been identified as abundant at synapses: neurabin and spinophilin (also known as neurabinII). These homologs are highly expressed in the hippocampus and share multiple targeting and binding domains, including a PP1-binding motif (RVxF) and an actin-binding domain, which is responsible for their postsynaptic spine localization (Fig. 2A) (Allen et al., 1997; Nakanishi et al., 1997; Grossman et al., 2002; Zito et al., 2004). By mutating the RVxF motif (neurabin ${ }^{\mathrm{F} 60 \mathrm{~A}}$; spinophilin ${ }^{\mathrm{F} 451 \mathrm{~A}}$ ), selective disruption of the neurabin-PP1 or spinophilin-PP1 holoenzymes can be achieved.

Electrophysiological studies indicate that neurabin not only promotes LTD, but also inhibits LTP induction (Hu et al., 2006, 2007). LTD and depotentiation involve dephosphorylation of GluA1 Ser845 and Ser831 (Lee et al., 2000); overexpression of WT neurabin increased PP1 localization to spines and promoted the dephosphorylation of GluA1 Ser845 and Ser831 following LTD induction ( $\mathrm{Hu}$ et al., 2007) (Figs. 2B, 3B). On the other hand, overexpression of neurabin ${ }^{\mathrm{F} 460 \mathrm{~A}}$ disrupted endogenous neurabin-PP1 interaction and led to a reduction in the amount of PP1 present at the synapse, suggesting a dominant negative effect ( $\mathrm{Hu}$ et al., 2007). Expression of neurabin ${ }^{\mathrm{F} 460 \mathrm{~A}}$ blocked LTD induction and lowered the threshold of LTP induction, whereas expression of WT neurabin blocked LTP induction and lowered the threshold of LTD induction (Hu et al., 2006). This suggests a bidirectional role of neurabin-targeted PP1 in synaptic plasticity (Fig. 3A). A potential phosphorylation site on neurabin (Ser 461) immediately after the RVxF motif modulates its binding affinity to PP1 (McAvoy et al., 1999; Gao et al., 2018). Accordingly, phosphomimetic mutation (S461E) of this site reduced PP1 interaction and blocked LTD (Gao et al., 2018). Interestingly, expression of the corresponding PP1-binding deficient mutant spinophilin ${ }^{\mathrm{F} 451 \mathrm{~A}}$ did not block LTD induction (Gao et al., 2018), suggesting that PP1 bound to spinophilin does not play a role in LTD induction in the hippocampus.

What is the possible mechanism underlying the different roles of neurabin- and spinophilin-bound PP1 in LTD induction? Despite their similarities, multiple lines of evidence have revealed that neurabin and spinophilin play different roles at the synapse, likely because of their significant sequence differences (Fig. 2A): (1) different phosphorylation sites in the N-terminal actin binding domain (1-285, with 1-144 being the core binding module) as well as greater sequence variability of the assisting binding module (145-285) (Barnes et al., 2004), which could lead to differential actin binding, and regulation by kinases; (2) significant divergence between the actin binding domain and the PP1-binding motif, dubbed the variable domain, underlies the distinct regulation of adrenergic GPCRs by spinophilin (X. Wang et al., 2005, 2007; Y. Chen et al., 2012) and adenosine A1 receptors by neurabin (Y. Chen et al., 2012); and (3) the phosphorylation site on neurabin adjacent to the PP1-binding motif (Ser461), which allows for phosphorylation-mediated regulation of PP1 binding, is not found on spinophilin (McAvoy et al., 1999; Gao et al., 2018). The difference between neurabin and spinophilin in their actin binding domain and variable domain domains (Fig. 2A) suggests the possibility of differential nano-domain localization and regulation within spines, which would result in differential targeting of PP1 to distinct subsets of substrates. This hypothesis needs to be tested in the future. The coiled-coil domains add complexity to these research questions, as they enable neurabin and spinophilin to dimerize with themselves (homodimerization), with each other (heterodimerization) (Oliver et al., 2002), and with the Rho GEF, Lfc (Ryan et al., 2005). However, the extent and significance of heterodimerization in vivo are not clear. Additionally, there is evidence that PP1 targeting by an individual PP1-interacting protein may vary depending on developmental stage and brain region (Baucum et al., 2012a,b).

In addition to neurabin and spinophilin, there are many PP1 targeting proteins present in synaptic spines. Of the known PP1 targeting proteins, $>200$ are widely expressed in the human brain (Sjostedt et al., 2020), with $\sim 50$ being localized in the human postsynaptic density (Bayes et al., 2011) (Fig. 1B). For 


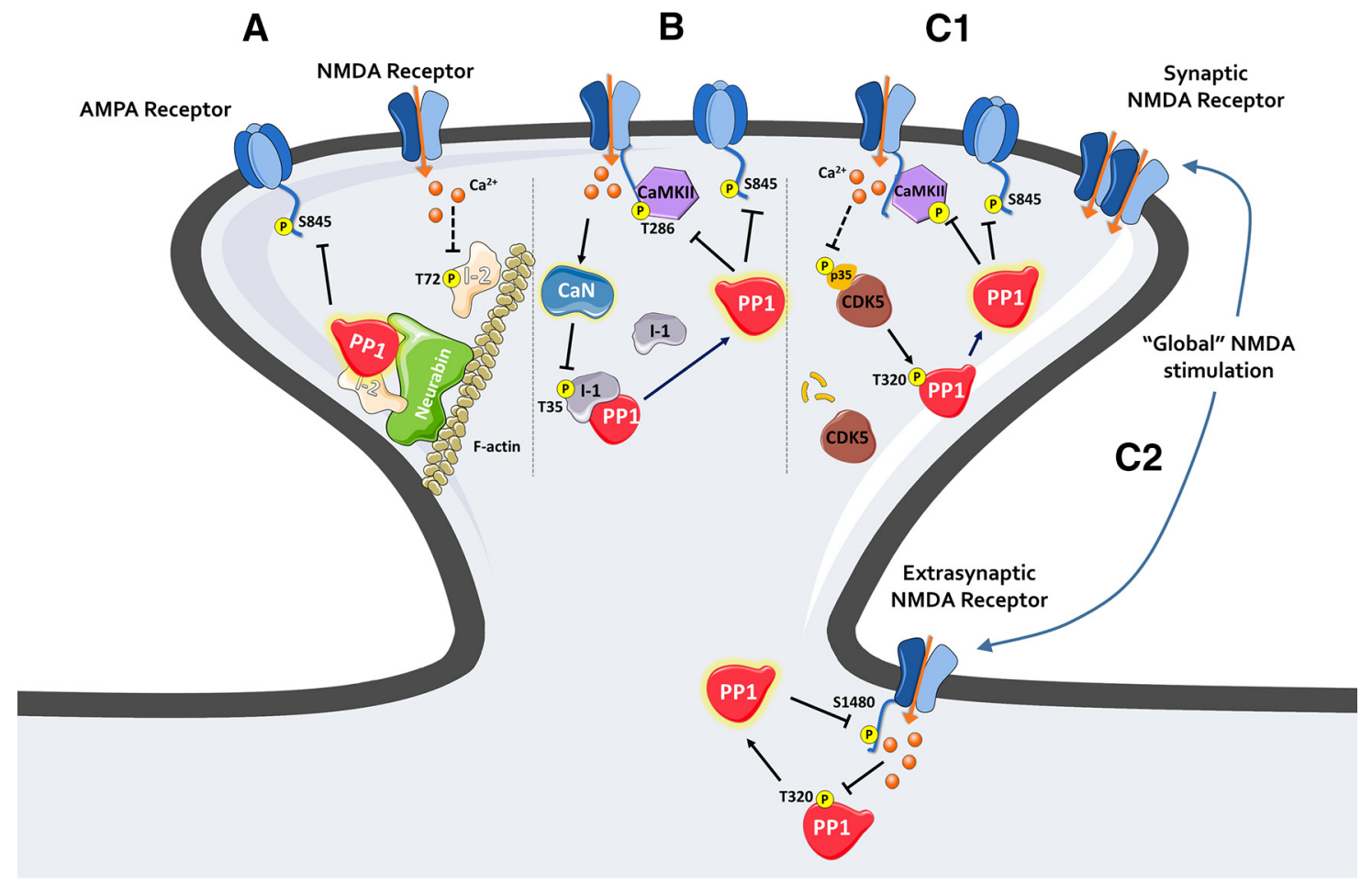

Figure 3. Multiple modes of PP1 activation and signaling in neurons. A, NMDAR activation leads to I-2 dephosphorylation at Thr72, and potentially increases I-2/neurabin-PP1 trimeric complex formation, to mediate PP1's effect on synaptic AMPARs. B, Phosphatase cascade model in LTD induction: Calcineurin (CaN), activated by calcium influx via NMDARs, dephosphorylates I-1 and relieves its inhibition on PP1, leading to PP1 activation and synaptic depression. $C_{1}$, Calcium influx via NMDARs leads to p35 proteasomal degradation and decreased CDK5 activity. This leads to decreased PP1 phosphorylation at Thr320, an inhibitory phosphorylation site on PP1, and synaptic PP1 activation. $\boldsymbol{C}_{2}$, Extrasynaptic PP1 activation requires global NMDAR activation. Synaptic NMDAR activation is probably needed for depolarization at extrasynaptic sites to relieve magnesium block so extrasynaptic NMDAR can be activated. Several mechanisms likely operate simultaneously at a given synapse. I-2 has been postulated to play a role in extrasynaptic PP1 regulation (Chiu et al., 2019). Spinophilin is a candidate scaffolding protein for extrasynaptic PP1 action on NMDAR and AMPAR.

example, the major postsynaptic scaffolds DLG-2 (or postsynaptic density 93) and DLG-3 (or SAP102) have been shown to bind PP1 in vitro (Hendrickx et al., 2009), but the role of these potential interactions in regulating synaptic plasticity has not been tested.

\section{PP1 regulates synaptic and extrasynaptic AMPARs and NMDARs}

AMPARs and NMDARs have many phosphorylation sites (Fig. $2 B$ shows sites discussed in this review) that are (1) potentially subject to direct dephosphorylation by PP1 and (2) important for their conductance, trafficking, and/or localization. The phosphorylation state of these receptors could affect basal synaptic transmission, which is regulated by constitutive receptor recycling and controlled lateral diffusion between synaptic compartments, where they readily respond to endogenously released neurotransmitter, and extrasynaptic compartments, where they generally do not respond to presynaptic glutamate release (Petrini et al., 2009). Notably, the location of these receptors determines not only the extent to which they are activated by synaptic glutamate release, but also their coupling to distinct downstream signaling pathways because of the differential regulation by scaffolding and signaling proteins within the neuron.

\section{AMPARs}

Nonselective disruption of PP1 and its targeting proteins with a small, $\mathrm{RVxF}$-containing peptide $\left(\mathrm{G}_{\mathrm{M}}\right.$-derived peptide) did not affect synaptic AMPAR and NMDAR currents in acute hippocampal slices (Morishita et al., 2001). Nevertheless, the manipulation blocked the induction of LTD, indicating that the peptide was successfully introduced into dendrites and exerted inhibitory effects. The lack of effect of disrupting PP1 targeting on synaptic transmission is consistent with prior pharmacological studies (Herron and Malenka, 1994; Hu et al., 2007; but see also Figurov et al., 1993). Interestingly, including purified, active PP1 in the recording pipette led to a "rundown," or decrease, of extrasynaptic AMPAR currents, but not synaptic AMPAR currents, over time (Morishita et al., 2001). While a lack of effect could be because of a low level of basal phosphorylation, LTD robustly decreased GluA1 phosphorylation at Ser845 (Lee et al., 2000), suggesting that there is sufficient level of basal AMPAR phosphorylation. This indicates that purified, active PP1 cannot access synaptic NMDARs and AMPARs in the postsynaptic density of hippocampal neurons under basal conditions. Further, it suggests that AMPAR regulation by PP1 is different between synaptic and extrasynaptic sites, the latter showing a greater similarity to effects seen in heterologous cell expression studies and effects on neuronal AMPAR currents induced by exogenous ligand application (Morishita et al., 2001).

In the striatum, nonselective disruption of PP1 holoenzymes had a pronounced effect on AMPAR responses to exogenously applied ligands. In acutely dissociated striatal neurons, the AMPAR rundown was prevented if a spinophilin-derived short peptide, which also contains an RVxF motif, was included in the recording pipette (Yan et al., 1999). In these experiments, including the PP1 pharmacological inhibitor okadaic acid in the recording pipette yielded similar results, suggesting that disrupting PP1 targeting is as effective as inhibiting PP1 enzymatic activity. Subsequent experiments demonstrated that spinophilin $\mathrm{KO}$, but not neurabin $\mathrm{KO}$, significantly attenuated the AMPAR current 
rundown in mice (Feng et al., 2000; Allen et al., 2006). Therefore, the regulation of AMPAR currents by PP1 may be primarily mediated by spinophilin in the striatum. However, there appear to be differences in PP1 targeting between brain regions, as PP1mediated AMPAR rundown in PFC was not affected by either neurabin or spinophilin KO (Allen et al., 2006).

Studies using nonselective inhibition of PP1 failed to show a role of PP1 in basal synaptic transmission in the hippocampus. However, an unexpected finding from studies of the neurabinPP1 holoenzyme challenges the idea that PP1 does not regulate synaptic AMPARs under basal conditions ( $\mathrm{Hu}$ et al., 2007). Expression of neurabin ${ }^{\mathrm{F} 60 \mathrm{~A}}$ decreased both amplitude and frequency of mEPSCs in cultured hippocampal slices ( $\mathrm{Hu}$ et al., 2007). In this case, the longer time scale of overexpression compared with small, inhibitory peptide infusion $\left(G_{M}, I-1\right.$ in Morishita et al., 2001) likely allows neurabin ${ }^{\mathrm{F} 460 \mathrm{~A}}$ protein to specifically downregulate neurabin-PP1 holoenzyme function in dendritic spines. The decreased mEPSC amplitude and frequency in neurabin ${ }^{\mathrm{F} 60 \mathrm{~A}}$-expressing neurons thus suggest that neurabin-bound PP1 positively regulates synaptic transmission in cultured hippocampal slices. Global disruption of PP1 activity using $\mathrm{G}_{\mathrm{M}}$ peptide might be expected to have broader effects than selective disruption of PP1-neurabin interaction by expression of neurabin ${ }^{\mathrm{F} 460 \mathrm{~A}}$; however, this may not be true for specific cellular processes, such as synaptic transmission. Expression of WT neurabin did not lead to a change in synaptic transmission in the hippocampal neurons (Terry-Lorenzo et al., 2005; Hu et al., 2007), suggesting that overexpression does not have an off-target effect in this physiological process. Therefore, the suppressive effect of neurabin ${ }^{\mathrm{F} 460 \mathrm{~A}}$ on synaptic transmission is likely specific and mediated by neurabin-bound PP1.

The striking difference in results, with selective disruption of neurabin-PP1 leading to an effect (Hu et al., 2007) that is not observed with nonselective disruption of PP1 holoenzymes (Morishita et al., 2001), suggests an intriguing complexity in PP1's regulation of AMPARs. These results could suggest the presence of an additional PP1 holoenzyme with a counterbalancing, or opposing, effect on synaptic transmission. Indeed, this is supported by the finding that pharmacologic inhibition of all PP1 holoenzymes rescued the synaptic transmission deficit in neurabin ${ }^{\mathrm{F} 40 \mathrm{~A}}$-expressing neurons but did not affect synaptic transmission in control neurons. Further studies suggest that neurabin-anchored PP1 increases synaptic transmission by dephosphorylating GluA2 at Ser880 (Hu et al., 2007), but the possible opposing PP1 holoenzyme and substrate(s) have not yet been identified. In contrast, increasing the targeting of PP1 to synapses via overexpression of WT neurabin did not alter basal synaptic transmission, consistent with the low basal phosphorylation of GluA2 Ser880 (States et al., 2008). Interestingly, LTD induction and depotentiation decreased GluA1 phosphorylation at Ser845 and Ser831, respectively (Lee et al., 2000), which is potentiated in CA1 cells overexpressing neurabin $(\mathrm{Hu}$ et al., 2007). Neurabin-targeted PP1 thus can possibly access different phospho-substrates at the synapse in basal versus LTD conditions.

\section{NMDARs}

NMDARs contribute little to basal synaptic transmission because of a voltage-dependent magnesium block at the resting membrane potential. However, they are critical for inducing synaptic plasticity at Sch-CA1 synapses. Regulation of the NMDARs by PP1 is thus of significance in plasticity research. NMDARs, like AMPARs, have many phosphorylation sites (Lee, 2006; Lussier et al., 2015). Although the corresponding kinases have been well identified, studies of phosphatases are limited, let alone the identity of associated PP1 targeting subunits. Nevertheless, two phosphorylation sites on the NMDAR are now known to be PP1 substrates in hippocampal neurons: Ser1303 and Ser1480 of GluN2B (Raveendran et al., 2009; Chiu et al., 2019). Ser1303 phosphorylation likely affects channel conductance (Liao et al., 2000), receptor desensitization (Tavalin and Colbran, 2017), and interaction with CaMKII (Strack et al., 2000; O'Leary et al., 2011), while Ser1480 phosphorylation regulates lateral diffusion of GluN2B-containing NMDARs (Chiu et al., 2019). The dephosphorylation of Ser1480 GluN2B by PP1 causes lateral translocation of extrasynaptic GluN2B-containing NMDARs to the synaptic site (Chiu et al., 2019). Because GluN2B-containing NMDAR currents have a longer decay time than GluN2A-containing NMDARS, increasing the proportion of GluN2B-containing NMDARs at the synapse will increase calcium influx into the spines on synaptic activation.

The relevant PP1-targeting proteins for these sites have not been established, but yotiao and spinophilin are known PP1- and NMDAR-binding proteins that emerge as strong candidates. In HEK 293 cells transfected with NMDAR subunits and the PP1 scaffolding protein yotiao, NMDAR currents increased when the yotiao-PP1 holoenzyme was disrupted with intracellular perfusion of $\mathrm{G}_{\mathrm{M}}$ peptide, an $\mathrm{RVxF}$-containing peptide inhibitor (Westphal et al., 1999). Since yotiao also acts as an A-kinase anchoring protein (i.e., a scaffold for PKA), this effect is likely because of a shift in the balance of phosphatase and kinase activity: without PP1, PKA action on the NMDAR will dominate. However, which phosphorylation site(s) are modulated by yotiao-PP1 was not examined in the above study. Although yotiao facilitates PP1 activity in HEK 293 cells, it remains unclear whether it is the major scaffolding protein in neurons, as the expression level of yotiao is very low in neurons. In contrast, spinophilin is a prominent synaptic scaffold for PP1 that can bind the NMDAR subunit GluN2B (Salek et al., 2019). Which phosphorylation site(s) on NMDAR may be regulated by spinophilin-PP1 is not clear, but NMDA application studies performed in hippocampal neurons of spinophilin $\mathrm{KO}$ mice indicated that spinophilin-bound PP1 negatively regulates NMDAR currents (Feng et al., 2000). Whether this reflects a change in synaptic NMDAR or extrasynaptic NMDAR currents is not clear. More work is needed to identify and characterize the PP1 targeting proteins involved in dephosphorylation of various NMDAR residues at synaptic versus extrasynaptic sites in neurons.

\section{Novel regulation of presynaptic machinery by PP1}

Recent studies suggest that PP1 not only regulates synaptic transmission via dephosphorylation of postsynaptic AMPARs, but also via modulation of glutamate release. The PP1 targeting protein myosin phosphatase targeting subunit 1 is now known to localize to the presynaptic terminal in addition to postsynaptic spines (Lontay et al., 2012), where it may regulate presynaptic machinery. In the axosomatic "giant synapse" between the acoustic nerve and bushy cells of the cochlear nucleus, PP1 inhibition attenuated presynaptic neurotransmitter release (Lontay et al., 2012). Similarly, inhibition of PP1 in cortical synaptosomes decreased $\mathrm{Ca}^{2+}$-dependent exocytosis (Lontay et al., 2012). This presynaptic role of PP1 appears to be mediated by dephosphorylation of Thr138 of SNAP-25, a component of the trans-SNARE complex critical for synaptic vesicle exocytosis (Horváth et al., 2017). Although it is unclear whether this regulation extends to other regions of the brain, including the hippocampus, these 
findings expand our understanding of the diverse roles of PP1 in the brain and present intriguing new lines of research.

\section{Inhibition of PP1 activity by small protein inhibitors and by C-terminal phosphorylation}

In addition to the targeting proteins that restrict PP1 activity and provide substrate specificity, there is a subset of PP1 regulatory proteins that strictly inhibit PP1 activity. These proteins, including inhibitor-1 (I-1) and DARPP-32, when phosphorylated by PKA at Thr35 (I-1) or Thr34 (DARPP-32), act as pseudo-substrates of PP1, inhibiting its activity by occupying its catalytic site. This simple, seemingly nonspecific inhibition of PP1 can be a powerful regulatory mechanism. DARPP-32, whose expression level is high in the striatum, but very low in the cortex and hippocampus, has been shown to play critical roles in the regulation of converging dopamine and glutamate signaling in medium spiny neurons. Because there are several excellent reviews on striatal DARPP-32 (see, e.g., Svenningsson et al., 2004), we focus here on PP1 regulation by I-1 in the hippocampus.

The standard model for PP1 activation during hippocampal LTD involves PP1 disinhibition at the synapse via PP2B-mediated dephosphorylation of I-1 at Thr35 (Fig. 3B). This model was first developed based on evidence from in vitro experiments in skeletal muscle (Cohen, 1989) where the protein levels of I-1 and PP1 approach a 1:1 molar ratio and strong basal PKA activity leads to a high level of I-1 phosphorylation at Thr35. In vitro studies suggest that PP2B dephosphorylates I-1 at Thr35 efficiently, thereby disinhibiting PP1. It was hypothesized that this cascade can be initiated in neurons by NMDAR-mediated calcium influx during LTD induction: PP2B is activated by calcium/calmodulin, and dephosphorylates I-1 at Thr35, thereby removing I-1's potent inhibition of PP1 and causing PP1 activation that ultimately results in synaptic depression (Lisman, 1989; Mulkey et al., 1994). Consistent with this hypothesis, at the SchCA1 synapse in acute hippocampal slices, both PP1 (Mulkey et al., 1993) and PP2B (Mulkey et al., 1994) are necessary for LTD induction; and PP2B is activated by the LTD-inducing stimulus via calcium-calmodulin binding. This model has also been applied to LTP. Given that high-frequency stimulation increases I-1 phosphorylation at Thr35 by PKA, increased PP1 inhibition by I-1 has also been hypothesized to be involved in the normal expression of LTP (Blitzer et al., 1998). However, evidence from I-1 KO mice suggests that this classical model is not involved in PP1 regulation during LTD and LTP at Sch-CA1 synapses. Indeed, the induction of LTD and LTP at Sch-CA1 is normal in I-1 KO mice (Allen et al., 2000). This result could be explained by the relatively low level of I-1 protein expression in CA1 neurons (Allen et al., 2000). On the other hand, the expression level of I-1 protein is very high in dentate gyrus granule cells; and correspondingly, LTP is defective in the lateral perforant path-granule cell synapse in I-1 KO mice (Allen et al., 2000). Whether LTD induction is affected at the lateral perforant path-granule synapse has not yet been examined, however. Interestingly, LTP induction is normal in the medial perforant path-granule cell synapse in I-1 KO mice (Allen et al., 2000), suggesting that I-1 may not contribute significantly to the regulation of PP1 in those synapses during LTP induction. The cause of this discrepancy between granule cell synapses is not known but speaks to the complexity of PP1 regulation even within a single cell. In summary, although the standard model might hold at some synapses, it does not appear to be a universal mechanism of PP1 regulation.

Another major model of PP1 inhibition at the synapse involves phosphorylation of PP1 itself (Fig. 3C1). Phosphorylation of a conserved threonine found in the C-termini of all PP1 isoforms (Thr320 in PP1 $\alpha$ ) inhibits PP1 activity. PP1 can auto-dephosphorylate this site (Dohadwala et al., 1994; Salvi et al., 2020). When PP1 is phosphorylated at this site, it will not be able to dephosphorylate other substrates. Consequently, phosphorylation of this site (pThr320) is a good inverse molecular marker for PP1 enzymatic activity. Using this marker, there is evidence that PP1 is activated downstream of NMDAR activation in a calcium-dependent manner in neurons (Hou et al., 2013). This PP1 activation pathway appears to depend on decreased activity of Cdk5, the primary kinase responsible for Thr320 phosphorylation in neurons, but not on calcineurin and I-1. Specifically, synaptic NMDAR activation leads to proteasomal degradation of $\mathrm{p} 35$, a regulatory subunit of $\mathrm{Cdk} 5$, which results in reduced Thr320 phosphorylation and thus disinhibition of PP1 (Hou et al., 2013) (Fig. 3C1). Interestingly, global (synaptic and extrasynaptic) activation of NMDARs has a more robust effect on PP1 activation than activation of synaptic NMDAR alone (Hou et al., 2013). Consistent with this, the extrasynaptic pool of PP1 is only activated by global NMDAR activation leading to dephosphorylation of GluN2B at Ser1480 (Chiu et al., 2019) (Fig. 3C2).

\section{Regulation of PP1 activity by I-2, an atypical PP1 regulator}

The roles of the inhibitory proteins I-1 and DARPP-32 in PP1 regulation are established in dentate gyrus and striatum, respectively. In hippocampus and cortex, I-2 appears to be the major regulator of PP1 in synaptic plasticity and memory formation.

I-2 has been shown to be an inhibitor of PP1 by numerous in vitro studies examining purified I-2 and I-2-PP1 dimer function (Cohen, 1989). I-2 has also been to shown to inhibit PP1 in many different cell types (Tung et al., 1995; Tang et al., 2008; Siddoway et al., 2013b; Lemaire and Bollen, 2020). In HEK 293 cells, ion irradiation led to increased I-2 phosphorylation at Ser43, I-2-PP1 dissociation, PP1 activation, and subsequent dephosphorylation of downstream cell-cycle-effector phospho-proteins (Tang et al., 2008). In neurons, I-2 plays an important role in a form of synaptic plasticity, homeostatic synaptic scaling. Downscaling following bicuculline treatment was associated with robust phosphorylation of I-2 at Ser43 (Siddoway et al., 2013b). A phospho-null mutation at this site (S43A) disrupted all aspects of the homeostatic downscaling process: blocking the reduction in surface GluA1 and GluA2, the reduction in mEPSC amplitude, and the decrease in GluA2 Ser880 phosphorylation (Siddoway et al., 2013b).

One mechanism of I-2 inhibition of PP1 activity involves amino acids $130-160$ of I-2, which form an extended $\alpha$-helix structure that interacts with PP1 along the hydrophobic and acidic grooves and blocks the active site (Hurley et al., 2007). I-2 can be phosphorylated at Thr72, which can then inhibit PP1 likely via some sort of occupation of its active site, but distinct from the pseudosubstrate mechanism of I-1 and DARPP-32 (Cohen, 1989; Lemaire and Bollen, 2020). The associated kinases for Thr72 phosphorylation include Cdk5, as demonstrated in both neuronal and non-neuronal cells (Li et al., 2007; Hou et al., 2013), and GSK3 $\beta$, as shown in vitro (S. D. Yang et al., 1981) and possibly in vivo (Szatmari et al., 2005; Chiu et al., 2019), the latter suggesting that I-2 might be a downstream effector of antipsychotic drugs, such as lithium (Costemale-Lacoste et al., 2016).

Recent evidence suggests that I-2 also regulates PP1 function by a mechanism other than inhibition of PP1 activity. Knocking down I-2, but not I-1, leads to robust changes in PP1 pThr320 in cortical neurons (Hou et al., 2013), suggesting that I-2 is a 
relevant endogenous regulator of PP1 activity in this neuronal population. Interestingly, the phosphorylation of PP1 at Thr320 increases after I-2 knockdown in cortical neurons, opposite to what would be predicted if I-2 acted as an inhibitor. Moreover, NMDAR signaling decreases pThr72 on I-2 and increases I-2PP1 complex formation (Hou et al., 2013) (Fig. 3A), which would be incompatible with PP1-mediated LTD induction if I-2 were merely an inhibitor. Moreover, chemical-LTD is defective in I-2 $\mathrm{kDa}$ hippocampal neurons, suggesting that (1) this NMDAR-I-2-PP1 signaling pathway is relevant to Hebbian synaptic plasticity, and (2) I-2 does not seem to be a PP1 inhibitor in this process. Finally, in vivo studies using an I-2 hemizygous mouse model and I-2 $\mathrm{kDa}$ rat model suggest that I-2 is a memory suppressor (H. Yang et al., 2015), in contrast to the memory improvement seen with PP1 inhibition (Genoux et al., 2002). These studies indicate that I-2 is a major PP1 regulator with an essential role in Hebbian-type synaptic plasticity and memory formation, but does not seem to accomplish this by inhibiting PP1 function. Consistent with this view, yeast genetic studies also conclude that I-2 can function as an activator of PP1 in addition to its inhibitory action toward PP1 (Tung et al., 1995).

How do we explain this positive regulation of PP1 by I-2? A hypothesis based on in vitro data has been put forth, that nascent PP1 requires I-2 binding for correct protein folding and/or maturation (interested readers are encouraged to read a recent indepth review on this topic, Lemaire and Bollen, 2020). This nascent PP1 hypothesis is attractive because it is consistent with observations that I-2's activating function on PP1 has been revealed mostly when I-2 is knocked out or down (Tung et al., 1995; Hou et al., 2013; H. Yang et al., 2015; Lemaire and Bollen, 2020). However, to date, there is no report on, or attempt for, the demonstration of the existence of nascent PP1 in cells. Until then, we prefer a different, but not necessarily mutually exclusive, explanation. The PP1 holoenzyme classically consists of PP1 and a single regulatory protein. However, there is evidence that PP1 can form multimeric complexes with its regulatory proteins. For example, PP1, neurabin, and I-2 have been shown to exist in a trimeric complex (Dancheck et al., 2011). Interestingly, an in vitro study has indicated that I-2 promotes the binding between PP1 and neurabin (Terry-Lorenzo et al., 2002a), thus providing a potential molecular basis for in vivo studies showing that I-2 is a positive regulator of PP1's negative role in memory formation (H. Yang et al., 2015). Consistent with this idea, manipulations of the individual components in the potential PP1-neurabin-I-2 complex cause similar deficits in LTD (Mulkey et al., 1993; Hu et al., 2006; Hou et al., 2013).

Additional trimeric complexes consisting of I-1 or I-2 have been reported, including PP1-GADD34-I-1 (Connor et al., 2001) and PP1-lemur tyrosine kinase 2-I-2 (H. Wang and Brautigan, 2002). Whether I-1 and I-2 can promote binding between PP1 and its scaffolding protein in these complexes is not clear. Finally, biochemical isolation of PP1 complexes in the brain has identified more novel components in these complexes, such as 14-3-3, Cdk5, and C-TAK1 (Agarwal-Mawal and Paudel, 2001; Platholi et al., 2008). The potential function of these PP1 multimeric complexes in synaptic plasticity remains unexplored.

In conclusion, underlying the many functions of PP1 are complex regulatory networks with heterogeneity between brain regions. These regulatory networks are composed of a vast number of targeting proteins and small protein inhibitors. Recent insights into the functions of individual PP1 holoenzymes, rather than general PP1 activity, have yielded new models of PP1 regulation and surprising new research avenues. Further mechanistic research on PP1 could have significant translational value, especially for patients affected by de novo mutations of $\mathrm{PP} 1 \beta$, which cause intellectual disability. More generally, PP1 is an attractive therapeutic target for neurologic conditions marked by impairments in learning and memory. Many questions remain about PP1, and continued efforts to understand its function and regulation will inform our understanding of physiological processes in the brain and beyond.

\section{References}

Agarwal-Mawal A, Paudel HK (2001) Neuronal Cdc2-like protein kinase $(\mathrm{Cdk} 5 / \mathrm{p} 25)$ is associated with protein phosphatase 1 and phosphorylates inhibitor-2. J Biol Chem 276:23712-23718.

Allen PB, Ouimet CC, Greengard P (1997) Spinophilin, a novel protein phosphatase 1 binding protein localized to dendritic spines. Proc Natl Acad Sci USA 94:9956-9961.

Allen PB, Hvalby O, Jensen V, Errington ML, Ramsay M, Chaudhry FA, Bliss TV, Storm-Mathisen J, Morris RG, Andersen P, Greengard P (2000) Protein phosphatase-1 regulation in the induction of long-term potentiation: heterogeneous molecular mechanisms. J Neurosci 20:3537-3543.

Allen PB, Zachariou V, Svenningsson P, Lepore AC, Centonze D, Costa C, Rossi S, Bender G, Chen G, Feng J, Snyder GL, Bernardi G, Nestler EJ, Yan Z, Calabresi P, Greengard P (2006) Distinct roles for spinophilin and neurabin in dopamine-mediated plasticity. Neuroscience 140:897-911.

Andrade EC, Nairn AC (2009) Mechanisms of neuroplasticity in addiction [electronic resource]: regulation of serine/threonine phosphatases and their roles in the striatum. PhD thesis, Department of Psychiatry, Yale University.

Barco A, Alarcon JM, Kandel ER (2002) Expression of constitutively active CREB protein facilitates the late phase of long-term potentiation by enhancing synaptic capture. Cell 108:689-703.

Barnes AP, Smith FD 3rd, VanDongen HM, VanDongen AM, Milgram SL (2004) The identification of a second actin-binding region in spinophilin/neurabin II. Brain Res Mol Brain Res 124:105-113.

Baucum AJ, Brown AM, Colbran RJ (2012a) Differential association of postsynaptic signaling protein complexes in striatum and hippocampus. J Neurochem 124:490-501.

Baucum AJ, Strack S, Colbran RJ (2012b) Age-dependent targeting of protein phosphatase 1 to $\mathrm{Ca}^{2+} /$ calmodulin-dependent protein kinase II by spinophilin in mouse striatum. PLoS One 7:e31554.

Bayes A, van de Lagemaat LN, Collins MO, Croning MD, Whittle IR, Choudhary JS, Grant SG (2011) Characterization of the proteome, diseases and evolution of the human postsynaptic density. Nat Neurosci 14:19-21.

Bertola D, Yamamoto G, Buscarilli M, Jorge A, Passos-Bueno MR, Kim C (2017) The recurrent PPP1CB mutation p.Pro49Arg in an additional Noonan-like syndrome individual: broadening the clinical phenotype. Am J Med Genet A 173:824-828.

Bertran MT, Mouilleron S, Zhou Y, Bajaj R, Uliana F, Kumar GS, van Drogen A, Lee R, Banerjee JJ, Hauri S, O’Reilly N, Gstaiger M, Page R, Peti W, Tapon N (2019) ASPP proteins discriminate between PP1 catalytic subunits through their SH3 domain and the PP1 C-tail. Nat Commun 10:771.

Bito H, Deisseroth K, Tsien RW (1996) CREB phosphorylation and dephosphorylation: $\mathrm{a} \mathrm{Ca}(2+)$ - and stimulus duration-dependent switch for hippocampal gene expression. Cell 87:1203-1214.

Blitzer RD, Connor JH, Brown GP, Wong T, Shenolikar S, Iyengar R, Landau EM (1998) Gating of CaMKII by cAMP-regulated protein phosphatase activity during LTP. Science 280:1940-1942.

Bollen M, Peti W, Ragusa MJ, Beullens M (2010) The extended PP1 toolkit: designed to create specificity. Trends Biochem Sci 35:450-458.

Booth DG, Takagi M, Sanchez-Pulido L, Petfalski E, Vargiu G, Samejima K, Imamoto N, Ponting CP, Tollervey D, Earnshaw WC, Vagnarelli $\mathrm{P}$ (2014) Ki-67 is a PP1-interacting protein that organises the mitotic chromosome periphery. Elife 3:e01641.

Bordelon JR, Smith Y, Nairn AC, Colbran RJ, Greengard P, Muly EC (2005) Differential localization of protein phosphatase-1alpha, beta and gamma1 isoforms in primate prefrontal cortex. Cereb Cortex 15:1928-1937. 
Brush MH, Guardiola A, Connor JH, Yao TP, Shenolikar S (2004) Deactylase inhibitors disrupt cellular complexes containing protein phosphatases and deacetylases. J Biol Chem 279:7685-7691.

Carmody LC, Bauman PA, Bass MA, Mavila N, DePaoli-Roach AA, Colbran RJ (2004) A protein phosphatase-1gammal isoform selectivity determinant in dendritic spine-associated neurabin. J Biol Chem 279:2171421723.

Carmody LC, Baucum AJ, Bass MA, Colbran RJ (2008) Selective targeting of the gammal isoform of protein phosphatase 1 to F-actin in intact cells requires multiple domains in spinophilin and neurabin. FASEB J 22:1660-1671.

Carrara M, Sigurdardottir A, Bertolotti A (2017) Decoding the selectivity of eIF2 $\alpha$ holophosphatases and PPP1R15A inhibitors. Nat Struct Mol Biol 24:708-716.

Chen R, Rato C, Yan Y, Crespillo-Casado A, Clarke HJ, Harding HP, Marciniak SJ, Read RJ, Ron D (2015) G-actin provides substrate-specificity to eukaryotic initiation factor 2alpha holophosphatases. Elife 4: e04871.

Chen Y, Liu Y, Cottingham C, McMahon L, Jiao K, Greengard P, Wang Q (2012) Neurabin scaffolding of adenosine receptor and RGS4 regulates anti-seizure effect of endogenous adenosine. J Neurosci 32:2683-2695.

Chiu AM, Wang J, Fiske MP, Hubalkova P, Barse L, Gray JA, Sanz-Clemente A (2019) NMDAR-activated PP1 dephosphorylates GluN2B to modulate NMDAR synaptic content. Cell Rep 28:332-341.e335.

Choy MS, Hieke M, Kumar GS, Lewis GR, Gonzalez-DeWhitt KR, Kessler RP, Stein BJ, Hessenberger M, Nairn AC, Peti W, Page R (2014) Understanding the antagonism of retinoblastoma protein dephosphorylation by PNUTS provides insights into the PP1 regulatory code. Proc Natl Acad Sci USA 111:4097-4102.

Choy MS, Yusoff P, Lee IC, Newton JC, Goh CW, Page R, Shenolikar S, Peti W (2015) Structural and functional analysis of the GADD34: PP1 eIF2alpha phosphatase. Cell Rep 11:1885-1891.

Chung HJ, Qian X, Ehlers M, Jan YN, Jan LY (2009) Neuronal activity regulates phosphorylation-dependent surface delivery of $\mathrm{G}$ protein-activated inwardly rectifying potassium channels. Proc Natl Acad Sci USA 106:629-634.

Cohen P (1989) The structure and regulation of protein phosphatases. Annu Rev Biochem 58:453-508.

Connor JH, Weiser DC, Li S, Hallenbeck JM, Shenolikar S (2001) Growth arrest and DNA damage-inducible protein GADD34 assembles a novel signaling complex containing protein phosphatase 1 and inhibitor 1 . Mol Cell Biol 21:6841-6850.

Costemale-Lacoste JF, Guilloux JP, Gaillard R (2016) The role of GSK-3 in treatment-resistant depression and links with the pharmacological effects of lithium and ketamine: a review of the literature. Encephale 42:156164.

da Cruz e Silva EF, Fox CA, Ouimet CC, Gustafson E, Watson SJ, Greengard P (1995) Differential expression of protein phosphatase 1 isoforms in mammalian brain. J Neurosci 15:3375-3389.

Dancheck B, Ragusa MJ, Allaire M, Nairn AC, Page R, Peti W (2011) Molecular investigations of the structure and function of the protein phosphatase 1-spinophilin-inhibitor 2 heterotrimeric complex. Biochemistry 50:1238-1246.

Das I, Krzyzosiak A, Schneider K, Wrabetz L, D’Antonio M, Barry N, Sigurdardottir A, Bertolotti A (2015) Preventing proteostasis diseases by selective inhibition of a phosphatase regulatory subunit. Science 348:239242

Deisseroth K, Mermelstein PG, Xia H, Tsien RW (2003) Signaling from synapse to nucleus: the logic behind the mechanisms. Curr Opin Neurobiol 13:354-365.

Dohadwala M, da Cruz e Silva EF, Hall FL, Williams RT, Carbonaro-Hall DA, Nairn AC, Greengard P, Berndt N (1994) Phosphorylation and inactivation of protein phosphatase 1 by cyclin-dependent kinases. Proc Natl Acad Sci USA 91:6408-6412.

Egloff MP, Johnson DF, Moorhead G, Cohen PT, Cohen P, Barford D (1997) Structural basis for the recognition of regulatory subunits by the catalytic subunit of protein phosphatase 1. EMBO J 16:1876-1887.

Fedoryshchak RO, Prõechová M, Butler AM, Lee R, O’Reilly N, Flynn HR, Snijders AP, Eder N, Ultanir S, Mouilleron S, Treisman R (2020) Molecular basis for substrate specificity of the Phactr1/PP1 phosphatase holoenzyme. Elife 9:e61509.
Feng J, Yan Z, Ferreira A, Tomizawa K, Liauw JA, Zhuo M, Allen PB, Ouimet CC, Greengard P (2000) Spinophilin regulates the formation and function of dendritic spines. Proc Natl Acad Sci USA 97:9287-9292.

Figurov A, Boddeke H, Muller D (1993) Enhancement of AMPA-mediated synaptic transmission by the protein phosphatase inhibitor calyculin A in rat hippocampal slices. Eur J Neurosci 5:1035-1041.

Gao J, Siddoway B, Huang Q, Xia H (2009) Inactivation of CREB mediated gene transcription by HDAC8 bound protein phosphatase. Biochem Biophys Res Commun 379:1-5.

Gao J, Hu XD, Yang H, Xia H (2018) Distinct roles of protein phosphatase 1 bound on neurabin and spinophilin and its regulation in AMPA receptor trafficking and LTD induction. Mol Neurobiol 55:7179-7186.

Genoux D, Haditsch U, Knobloch M, Michalon A, Storm D, Mansuy IM (2002) Protein phosphatase 1 is a molecular constraint on learning and memory. Nature 418:970-975.

Graff J, Koshibu K, Jouvenceau A, Dutar P, Mansuy IM (2010) Protein phosphatase 1-dependent transcriptional programs for long-term memory and plasticity. Learn Mem 17:355-363.

Gripp KW, Aldinger KA, Bennett JT, Baker L, Tusi J, Powell-Hamilton N, Stabley D, Sol-Church K, Timms AE, Dobyns WB (2016) A novel rasopathy caused by recurrent de novo missense mutations in PPP1CB closely resembles Noonan syndrome with loose anagen hair. Am J Med Genet A 170:2237-2247.

Grossman SD, Hsieh-Wilson LC, Allen PB, Nairn AC, Greengard P (2002) The actin-binding domain of spinophilin is necessary and sufficient for targeting to dendritic spines. Neuromolecular Med 2:61-69.

Hamdan FF, Srour M, Capo-Chichi JM, Daoud H, Nassif C, Patry L, Massicotte C, Ambalavanan A, Spiegelman D, Diallo O, Henrion E, Dionne-Laporte A, Fougerat A, Pshezhetsky AV, Venkateswaran S, Rouleau GA, Michaud JL (2014) De novo mutations in moderate or severe intellectual disability. PLoS Genet 10:e1004772.

Hedou GF, Koshibu K, Farinelli M, Kilic E, Gee CE, Kilic U, Baumgartel K, Hermann DM, Mansuy IM (2008) Protein phosphatase 1-dependent bidirectional synaptic plasticity controls ischemic recovery in the adult brain. J Neurosci 28:154-162.

Hendrickx A, Beullens M, Ceulemans H, Den Abt T, Van Eynde A, Nicolaescu E, Lesage B, Bollen M (2009) Docking motif-guided mapping of the interactome of protein phosphatase-1. Chem Biol 16:365-371.

Heroes E, Lesage B, Gornemann J, Beullens M, Van Meervelt L, Bollen M (2013) The PP1 binding code: a molecular-lego strategy that governs specificity. FEBS J 280:584-595.

Herron CE, Malenka RC (1994) Activity-dependent enhancement of synaptic transmission in hippocampal slices treated with the phosphatase inhibitor calyculin A. J Neurosci 14:6013-6020.

Hoermann B, Kokot T, Helm D, Heinzlmeir S, Chojnacki JE, Schubert T, Ludwig C, Berteotti A, Kurzawa N, Kuster B, Savitski MM, Kohn M (2020) Dissecting the sequence determinants for dephosphorylation by the catalytic subunits of phosphatases PP1 and PP2A. Nat Commun 11:3583.

Horváth D, Tamás I, Sipos A, Darula Z, Bécsi B, Nagy D, Iván J, Erdődi F, Lontay B (2017) Myosin phosphatase and RhoA-activated kinase modulate neurotransmitter release by regulating SNAP- 25 of SNARE complex. PLoS One 12:e0177046.

Hou H, Sun L, Siddoway BA, Petralia RS, Yang H, Gu H, Nairn AC, Xia H (2013) Synaptic NMDA receptor stimulation activates PP1 by inhibiting its phosphorylation by Cdk5. J Cell Biol 203:521-535.

Hu XD, Huang Q, Roadcap DW, Shenolikar SS, Xia H (2006) Actin-associated neurabin-protein phosphatase-1 complex regulates hippocampal plasticity. J Neurochem 98:1841-1851.

Hu XD, Huang Q, Yang X, Xia H (2007) Differential regulation of AMPA receptor trafficking by neurabin-targeted synaptic protein phosphatase-1 in synaptic transmission and long-term depression in hippocampus. J Neurosci 27:4674-4686

Hu XD, Liu YN, Zhang ZY, Ma ZA, Suo ZW, Yang X (2015) Spinophilin-targeted protein phosphatase-1 alleviated inflammatory pain by negative control of MEK/ERK signaling in spinal cord dorsal horn of rats. J Neurosci 35:13989-14001.

Hurley TD, Yang J, Zhang L, Goodwin KD, Zou Q, Cortese M, Dunker AK, DePaoli-Roach AA (2007) Structural basis for regulation of protein phosphatase 1 by inhibitor-2. J Biol Chem 282:28874-28883. 
Jouvenceau A, Hedou G, Potier B, Kollen M, Dutar P, Mansuy IM (2006) Partial inhibition of PP1 alters bidirectional synaptic plasticity in the hippocampus. Eur J Neurosci 24:564-572.

Koshibu K, Graff J, Beullens M, Heitz FD, Berchtold D, Russig H, Farinelli M, Bollen M, Mansuy IM (2009) Protein phosphatase 1 regulates the histone code for long-term memory. J Neurosci 29:13079-13089.

Koshibu K, Graff J, Mansuy IM (2011) Nuclear protein phosphatase-1: an epigenetic regulator of fear memory and amygdala long-term potentiation. Neuroscience 173:30-36.

Kumar GS, Gokhan E, De Munter S, Bollen M, Vagnarelli P, Peti W, Page R (2016) The Ki-67 and RepoMan mitotic phosphatases assemble via an identical, yet novel mechanism. Elife 5:e16539.

Kwon YG, Huang HB, Desdouits F, Girault JA, Greengard P, Nairn AC (1997) Characterization of the interaction between DARPP-32 and protein phosphatase 1 (PP-1): DARPP-32 peptides antagonize the interaction of PP-1 with binding proteins. Proc Natl Acad Sci USA 94:35363541.

Lee HK (2006) Synaptic plasticity and phosphorylation. Pharmacol Ther $112: 810-832$.

Lee HK, Barbarosie M, Kameyama K, Bear MF, Huganir RL (2000) Regulation of distinct AMPA receptor phosphorylation sites during bidirectional synaptic plasticity. Nature 405:955-959.

Lemaire S, Bollen M (2020) Protein phosphatase-1: dual activity regulation by inhibitor-2. Biochem Soc Trans 48:2229-2240.

Li T, Chalifour LE, Paudel HK (2007) Phosphorylation of protein phosphatase 1 by cyclin-dependent protein kinase 5 during nerve growth factorinduced PC12 cell differentiation. J Biol Chem 282:6619-6628.

Liao GY, Kreitzer MA, Sweetman BJ, Leonard JP (2000) The postsynaptic density protein PSD-95 differentially regulates insulin- and Src-mediated current modulation of mouse NMDA receptors expressed in Xenopus oocytes. J Neurochem 75:282-287.

Lin CH, Lin WD, Chou IC, Lee IC, Fan HC, Hong SY (2018) Epileptic spasms in PPP1CB-associated Noonan-like syndrome: a case report with clinical and therapeutic implications. BMC Neurol 18:150.

Lisman J (1989) A mechanism for the Hebb and the anti-Hebb processes underlying learning and memory. Proc Natl Acad Sci USA 86:95749578.

Lontay B, Serfozo Z, Gergely P, Ito M, Hartshorne DJ, Erdodi F (2004) Localization of myosin phosphatase target subunit 1 in rat brain and in primary cultures of neuronal cells. J Comp Neurol 478:72-87.

Lontay B, Pál B, Serföző Z, Köszeghy Á, Szücs G, Rusznák Z, Erdődi F (2012) Protein phosphatase-1M and Rho-kinase affect exocytosis from cortical synaptosomes and influence neurotransmission at a glutamatergic giant synapse of the rat auditory system. J Neurochem 123:84-99.

Lussier MP, Sanz-Clemente A, Roche KW (2015) Dynamic regulation of Nmethyl-D-aspartate (NMDA) and alpha-amino-3-hydroxy-5-methyl-4isoxazolepropionic acid (AMPA) receptors by posttranslational modifications. J Biol Chem 290:28596-28603.

Ma L, Bayram Y, McLaughlin HM, Cho MT, Krokosky A, Turner CE, Lindstrom K, Bupp CP, Mayberry K, Mu W, Bodurtha J, Weinstein V, Zadeh N, Alcaraz W, Powis Z, Shao Y, Scott DA, Lewis AM, White JJ, Jhangiani SN, et al. (2016) De novo missense variants in PPP1CB are associated with intellectual disability and congenital heart disease. Hum Genet 135:1399-1409.

Malinow R, Malenka RC (2002) AMPA receptor trafficking and synaptic plasticity. Annu Rev Neurosci 25:103-126.

McAvoy T, Allen PB, Obaishi H, Nakanishi H, Takai Y, Greengard P, Nairn AC, Hemmings HC Jr (1999) Regulation of neurabin I interaction with protein phosphatase 1 by phosphorylation. Biochemistry 38:1294312949.

Morishita W, Connor JH, Xia H, Quinlan EM, Shenolikar S, Malenka RC (2001) Regulation of synaptic strength by protein phosphatase 1. Neuron 32:1133-1148.

Mulkey RM, Herron CE, Malenka RC (1993) An essential role for protein phosphatases in hippocampal long-term depression. Science 261:10511055.

Mulkey RM, Endo S, Shenolikar S, Malenka RC (1994) Involvement of a calcineurin/inhibitor-1 phosphatase cascade in hippocampal long-term depression. Nature 369:486-488.

Nakanishi H, Obaishi H, Satoh A, Wada M, Mandai K, Satoh K, Nishioka H, Matsuura Y, Mizoguchi A, Takai Y (1997) Neurabin: a novel neural tissue-specific actin filament-binding protein involved in neurite formation. J Cell Biol 139:951-961.

O'Leary H, Liu WH, Rorabaugh JM, Coultrap SJ, Bayer KU (2011) Nucleotides and phosphorylation bi-directionally modulate $\mathrm{Ca}^{2+} / \mathrm{cal}-$ modulin-dependent protein kinase II (CaMKII) binding to the $\mathrm{N}$ methyl-D-aspartate (NMDA) receptor subunit GluN2B. J Biol Chem 286:31272-31281.

Oliver CJ, Terry-Lorenzo RT, Elliott E, Bloomer WA, Li S, Brautigan DL, Colbran RJ, Shenolikar S (2002) Targeting protein phosphatase 1 (PP1) to the actin cytoskeleton: the neurabin I/PP1 complex regulates cell morphology. Mol Cell Biol 22:4690-4701.

Ouimet CC, da Cruz e Silva EF, Greengard P (1995) The alpha and gamma 1 isoforms of protein phosphatase 1 are highly and specifically concentrated in dendritic spines. Proc Natl Acad Sci USA 92:3396-3400.

Petrini EM, Lu J, Cognet L, Lounis B, Ehlers MD, Choquet D (2009) Endocytic trafficking and recycling maintain a pool of mobile surface AMPA receptors required for synaptic potentiation. Neuron 63:92-105.

Platholi J, Heerdt PM, Lim Tung HY, Hemmings HC Jr (2008) Activation of brain protein phosphatase-1(I) following cardiac arrest and resuscitation involving an interaction with 14-3-3 gamma. J Neurochem 105:20292038.

Pribiag H, Stellwagen D (2013) TNF-alpha downregulates inhibitory neurotransmission through protein phosphatase 1-dependent trafficking of GABA(A) receptors. J Neurosci 33:15879-15893.

Ragusa MJ, Dancheck B, Critton DA, Nairn AC, Page R, Peti W (2010) Spinophilin directs protein phosphatase 1 specificity by blocking substrate binding sites. Nat Struct Mol Biol 17:459-464.

Raveendran R, Devi Suma Priya S, Mayadevi M, Steephan M, Santhoshkumar TR, Cheriyan J, Sanalkumar R, Pradeep KK, James J, Omkumar RV (2009) Phosphorylation status of the NR2B subunit of NMDA receptor regulates its interaction with calcium/calmodulin-dependent protein kinase II. J Neurochem 110:92-105.

Ryan XP, Alldritt J, Svenningsson P, Allen PB, Wu GY, Nairn AC, Greengard P (2005) The Rho-specific GEF Lfc interacts with neurabin and spinophilin to regulate dendritic spine morphology. Neuron 47:85100

Salek AB, Edler MC, McBride JP, Baucum AJ (2019) Spinophilin regulates phosphorylation and interactions of the GluN2B subunit of the $\mathrm{N}$ methyl-D-aspartate receptor. J Neurochem 151:185-203.

Salvi F, Hoermann B, Garcia J, Fontanillo M, Derua R, Beullens M, Bollen M, Barabas O, Kohn M (2020) Towards dissecting the mechanism of protein phosphatase-1 inhibition by its C-terminal phosphorylation. Chembiochem. Advance online publication. Retrieved Oct 21, 2020. doi: 10.1002/cbic.202000669.

Sharma K, Schmitt S, Bergner CG, Tyanova S, Kannaiyan N, ManriqueHoyos N, Kongi K, Cantuti L, Hanisch UK, Philips MA, Rossner MJ, Mann M, Simons M (2015) Cell type- and brain region-resolved mouse brain proteome. Nat Neurosci 18:1819-1831.

Siddoway B, Hou H, Yang J, Sun L, Yang H, Wang GY, Xia H (2013a) Potassium channel Kv2.1 is regulated through protein phosphatase-1 in response to increases in synaptic activity. Neurosci Lett 583:142-147.

Siddoway BA, Altimimi HF, Hou H, Petralia RS, Xu B, Stellwagen D, Xia H (2013b) An essential role for inhibitor-2 regulation of protein phosphatase-1 in synaptic scaling. J Neurosci 33:11206-11211.

Siddoway B, Hou H, Yang H, Petralia R, Xia H (2014) Synaptic activity bidirectionally regulates a novel sequence-specific $\mathrm{S}-\mathrm{Q}$ phosphoproteome in neurons. J Neurochem 128:841-851.

Sjostedt E, Zhong W, Fagerberg L, Karlsson M, Mitsios N, Adori C, Oksvold P, Edfors F, Limiszewska A, Hikmet F, Huang J, Du LY, Lin L, Dong Z, Yang L, Liu X, Jiang H, Xu X, Wang J, Yang H, et al. (2020) An atlas of the protein-coding genes in the human, pig, and mouse brain. Science 367:eaay5947.

States BA, Khatri L, Ziff EB (2008) Stable synaptic retention of serine-880phosphorylated GluR2 in hippocampal neurons. Mol Cell Neurosci 38:189-202.

Strack S, Barban MA, Wadzinski BE, Colbran RJ (1997) Differential inactivation of postsynaptic density-associated and soluble $\mathrm{Ca}^{2+} /$ calmodulin-dependent protein kinase II by protein phosphatases 1 and $2 \mathrm{~A}$. J Neurochem 68:2119-2128.

Strack S, Kini S, Ebner FF, Wadzinski BE, Colbran RJ (1999) Differential cellular and subcellular localization of protein phosphatase 1 isoforms in brain. J Comp Neurol 413:373-384. 
Strack S, McNeill RB, Colbran RJ (2000) Mechanism and regulation of calcium/calmodulin-dependent protein kinase II targeting to the NR2B subunit of the N-methyl-D-aspartate receptor. J Biol Chem 275:2379823806.

Svenningsson P, Nishi A, Fisone G, Girault JA, Nairn AC, Greengard P (2004) DARPP-32: an integrator of neurotransmission. Annu Rev Pharmacol Toxicol 44:269-296.

Szatmari E, Habas A, Yang P, Zheng JJ, Hagg T, Hetman M (2005) A positive feedback loop between glycogen synthase kinase 3 beta and protein phosphatase 1 after stimulation of NR2B NMDA receptors in forebrain neurons. J Biol Chem 280:37526-37535.

Tang X, Hui ZG, Cui XL, Garg R, Kastan MB, Xu B (2008) A novel ATM-dependent pathway regulates protein phosphatase 1 in response to DNA damage. Mol Cell Biol 28:2559-2566.

Tavalin SJ, Colbran RJ (2017) CaMKII-mediated phosphorylation of GluN2B regulates recombinant NMDA receptor currents in a chloride-dependent manner. Mol Cell Neurosci 79:45-52.

Terrak M, Kerff F, Langsetmo K, Tao T, Dominguez R (2004) Structural basis of protein phosphatase 1 regulation. Nature 429:780-784.

Terry-Lorenzo RT, Inoue M, Connor JH, Haystead TA, Armbruster BN, Gupta RP, Oliver CJ, Shenolikar S (2000) Neurofilament-L is a protein phosphatase-1-binding protein associated with neuronal plasma membrane and postsynaptic density. J Biol Chem 275:2439-2446.

Terry-Lorenzo RT, Elliot E, Weiser DC, Prickett TD, Brautigan DL, Shenolikar S (2002a) Neurabins recruit protein phosphatase-1 and inhibitor-2 to the actin cytoskeleton. J Biol Chem 277:46535-46543.

Terry-Lorenzo RT, Carmody LC, Voltz JW, Connor JH, Li S, Smith FD, Milgram SL, Colbran RJ, Shenolikar S (2002b) The neuronal actin-binding proteins, neurabin I and neurabin II, recruit specific isoforms of protein phosphatase-1 catalytic subunits. J Biol Chem 277:27716-27724.

Terry-Lorenzo RT, Roadcap DW, Otsuka T, Blanpied TA, Zamorano PL, Garner CC, Shenolikar S, Ehlers MD (2005) Neurabin/protein phosphatase-1 complex regulates dendritic spine morphogenesis and maturation. Mol Biol Cell 16:2349-2362.

Thiels E, Norman ED, Barrionuevo G, Klann E (1998) Transient and persistent increases in protein phosphatase activity during long-term depression in the adult hippocampus in vivo. Neuroscience 86:1023-1029.

Thul PJ, Åkesson L, Wiking M, Mahdessian D, Geladaki A, Ait Blal H, Alm T, Asplund A, Björk L, Breckels LM, Bäckström A, Danielsson F, Fagerberg L, Fall J, Gatto L, Gnann C, Hober S, Hjelmare M, Johansson F, Lee S, et al. (2017) A subcellular map of the human proteome. Science 356:eaal3321.

Tomita S, Stein V, Stocker TJ, Nicoll RA, Bredt DS (2005) Bidirectional synaptic plasticity regulated by phosphorylation of stargazin-like TARPs. Neuron 45:269-277.

Trinkle-Mulcahy L, Ajuh P, Prescott A, Claverie-Martin F, Cohen S, Lamond AI, Cohen P (1999) Nuclear organisation of NIPP1, a regulatory subunit of protein phosphatase 1 that associates with pre-mRNA splicing factors. J Cell Sci 112:157-168.

Trinkle-Mulcahy L, Andersen J, Lam YW, Moorhead G, Mann M, Lamond AI (2006) Repo-Man recruits PP1 gamma to chromatin and is essential for cell viability. J Cell Biol 172:679-692.

Tsaytler P, Harding HP, Ron D, Bertolotti A (2011) Selective inhibition of a regulatory subunit of protein phosphatase 1 restores proteostasis. Science 332:91-94.
Tung HY, Wang W, Chan CS (1995) Regulation of chromosome segregation by Glc8p, a structural homolog of mammalian inhibitor 2 that functions as both an activator and an inhibitor of yeast protein phosphatase 1 . Mol Cell Biol 15:6064-6074.

Turrigiano GG, Leslie KR, Desai NS, Rutherford LC, Nelson SB (1998) Activity-dependent scaling of quantal amplitude in neocortical neurons. Nature 391:892-896.

Uhlen M, Fagerberg L, Hallstrom BM, Lindskog C, Oksvold P, Mardinoglu A, Sivertsson A, Kampf C, Sjostedt E, Asplund A, Olsson I, Edlund K, Lundberg E, Navani S, Szigyarto CA, Odeberg J, Djureinovic D, Takanen JO, Hober S, Alm T, et al. (2015) Proteomics: tissue-based map of the human proteome. Science 347:1260419.

Vecsey CG, Hawk JD, Lattal KM, Stein JM, Fabian SA, Attner MA, Cabrera SM, McDonough CB, Brindle PK, Abel T, Wood MA (2007) Histone deacetylase inhibitors enhance memory and synaptic plasticity via CREB: CBP-dependent transcriptional activation. J Neurosci 27:6128-6140.

Wakula P, Beullens M, Ceulemans H, Stalmans W, Bollen M (2003) Degeneracy and function of the ubiquitous RVXF motif that mediates binding to protein phosphatase-1. J Biol Chem 278:18817-18823.

Wang H, Brautigan DL (2002) A novel transmembrane Ser/Thr kinase complexes with protein phosphatase-1 and inhibitor-2. J Biol Chem 277:49605-49612.

Wang X, Zeng W, Soyombo AA, Tang W, Ross EM, Barnes AP, Milgram SL, Penninger JM, Allen PB, Greengard P, Muallem S (2005) Spinophilin regulates $\mathrm{Ca}^{2+}$ signalling by binding the N-terminal domain of RGS2 and the third intracellular loop of G-protein-coupled receptors. Nat Cell Biol 7:405-411.

Wang X, Zeng W, Kim MS, Allen PB, Greengard P, Muallem S (2007) Spinophilin/neurabin reciprocally regulate signaling intensity by $\mathrm{G}$ protein-coupled receptors. EMBO J 26:2768-2776.

Westphal RS, Tavalin SJ, Lin JW, Alto NM, Fraser ID, Langeberg LK, Sheng M, Scott JD (1999) Regulation of NMDA receptors by an associated phosphatase-kinase signaling complex. Science 285:93-96.

Woo NH, Abel T, Nguyen PV (2002) Genetic and pharmacological demonstration of a role for cyclic AMP-dependent protein kinase-mediated suppression of protein phosphatases in gating the expression of late LTP. Eur J Neurosci 16:1871-1876.

Yan Z, Hsieh-Wilson L, Feng J, Tomizawa K, Allen PB, Fienberg AA, Nairn AC, Greengard P (1999) Protein phosphatase 1 modulation of neostriatal AMPA channels: regulation by DARPP-32 and spinophilin. Nat Neurosci 2:13-17.

Yang H, Hou H, Pahng A, Gu H, Nairn AC, Tang YP, Colombo PJ, Xia H (2015) Protein phosphatase-1 inhibitor-2 is a novel memory suppressor. J Neurosci 35:15082-15087.

Yang SD, Vandenheede JR, Merlevede W (1981) Identification of inhibitor-2 as the ATP-mg-dependent protein phosphatase modulator. J Biol Chem 256:10231-10234.

Zambrano RM, Marble M, Chalew SA, Lilje C, Vargas A, Lacassie Y (2017) Further evidence that variants in PPP1CB cause a rasopathy similar to Noonan syndrome with loose anagen hair. Am J Med Genet A 173:565567.

Zito K, Knott G, Shepherd GM, Shenolikar S, Svoboda K (2004) Induction of spine growth and synapse formation by regulation of the spine actin cytoskeleton. Neuron 44:321-334. 